\title{
Inhibition by Tamoxifen of the stimulatory action of FSH on oestradiol-17 $\beta$ synthesis by rat ovaries in vitro
}

\author{
J. Watson and J. W. H. Howson \\ Department of Biochemistry, University of Strathclyde, Todd Centre, \\ 31 Taylor Street, Glasgow G4 ONR, U.K.
}

Previous studies (Watson, Anderson, Alam, O'Grady \& Heald, 1975) have established that the compound Tamoxifen (ICI 46,474) either delays or inhibits implantation in the rat depending on the dose. This effect on implantation is associated with delay or prevention of the oestrogen surge normally required for implantation in the rat, and studies in vitro have demonstrated that at least part of the antifertility action of Tamoxifen is to inhibit directly the ovarian synthesis of oestradiol (Watson \& Alam, 1976). Because the site of the inhibition appears to be at the aromatizing system (Watson \& Alam, 1976) and FSH has been reported as having a stimulatory effect on the aromatizing enzyme complex (Moon, Dorrington \& Armstrong, 1975), the purpose of the present investigation was to determine whether Tamoxifen acts by blocking the stimulatory action of FSH.

Sprague-Dawley rats of the Holtzman strain were used and ovaries were removed at $10.00 \mathrm{~h}$ on the days of the experiments from animals at Day 4 of pregnancy or at various stages of the oestrous cycle. In all experiments at least 6 animals were used at each of the specified times. The ovaries were bilaterally removed and placed whole in chilled saline. Pooled tissue was then minced and equal amounts of tissue (approximately $30 \mathrm{mg}$ ) distributed in incubation flasks. Incubations were carried out with shaking for $3 \mathrm{~h}$ at $37^{\circ} \mathrm{C}$ in $3 \mathrm{ml}$ Medium 199 (Wellcome Reagents Ltd, Beckenham, Kent) containing $\left[4-{ }^{14} \mathrm{C}\right]$ androstenedione or $\left[7(\mathrm{n})-{ }^{3} \mathrm{H}\right]$ testosterone $(\mathrm{sp}$. act. $60 \mathrm{mCi} / \mathrm{mmol}$ and $8 \mathrm{Ci} / \mathrm{mmol}$ respectively; Radiochemical Centre, Amersham, Bucks, U.K.). The doses tested were $15 \mu \mathrm{g}$ Tamoxifen and $10 \mu \mathrm{g}$ FSH separately or together: neither was added to control incubations.

The radioactive oestradiol secreted by the ovarian tissue was isolated and purified by thin-layer chromatography on silica as previously described (Watson \& Alam, 1976) except that dichloromethane-diethyl ether $(5: 2 \mathrm{v} / \mathrm{v})$ was used as the developing solvent. Radioactivity was then measured with a Nuclear Chicago Isocap/300 liquid scintillation counter linked to a pseudo-on-line computing system (Seaton, 1974). The identity of the purified oestradiol was confirmed by both gas liquid chromatography and recrystallization of representative samples to constant specific activity. Isolated oestradiol from a series of pooled samples had a retention time which was identical to external and internal standards of authentic oestradiol on $3 \%$ SE30 and 3\% OV17 gas chromatography columns (Applied Science Gas Chrom Q. support, 80-100 mesh) at several temperatures. The addition of $10 \mathrm{mg}$ oestradiol to material isolated from an incubation with $\left[{ }^{14} \mathrm{C}\right]$ androstenedione gave the following specific activities at successive crystallizations: 272, 294 and $302 \mathrm{~d} / \mathrm{min} /$ mg.

It can be seen clearly from Table 1 that with ovarian tissue from pregnant rats FSH caused a highly significant increase in the incorporation of androstenedione $(44 \%)$ or testosterone $(89 \%)$ into oestradiol relative to control incubations, while Tamoxifen caused significant decreases of 33 and $38 \%$ respectively. When FSH and Tamoxifen were present, the stimulatory action of FSH was completely abolished and the incorporation of both precursors appeared to be slightly less than that observed with Tamoxifen alone.

Similar results were obtained with ovarian tissue from non-pregnant rats (Table 1). FSH increased the incorporation of androstenedione and testosterone into oestradiol by 14 and $33 \%$ respectively, while Tamoxifen decreased their incorporation by 19 and $25 \%$ respectively. Again the stimulatory effect of FSH was completely abolished when Tamoxifen and FSH were present, and the degree of incorporation of the precursors was of the same order as that obtained in the presence of Tamoxifen alone. 
Table 1. Effects (mean \pm S.E.M.) of FSH and Tamoxifen on oestradiol production (d/min/100 mg tissue) from $1.0 \mu \mathrm{Ci}\left[4-^{14}\right]$ androstenedione or $1.0 \mu \mathrm{Ci}\left[7(\mathrm{n})-{ }^{3} \mathrm{H}\right]$ testosterone by ovarian tissue of pregnant or non-pregnant rats (4/group)

\begin{tabular}{lccccc}
\hline & \multicolumn{2}{c}{ Pregnant } & \multicolumn{2}{c}{ Non-pregnant } \\
\cline { 2 - 3 } \cline { 5 - 6 } Treatment & {$\left[{ }^{14} \mathrm{C}\right]$ Androstenedione } & {$\left[{ }^{3} \mathrm{H}\right]$ Testosterone } & & {$\left[{ }^{14} \mathrm{C}\right]$ Androstenedione } & {$\left[{ }^{3} \mathrm{H}\right]$ Testosterone } \\
\hline None (control) & $4263 \pm 136$ & $3233 \pm 218$ & & $2675 \pm 259$ & $2179 \pm 136$ \\
FSH $(15 \mu \mathrm{g})$ & $6161 \pm 275^{*}$ & $6118 \pm 280^{*}$ & & $3075 \pm 57$ & $2900 \pm 284 \dagger$ \\
Tamoxifen $(10 \mu \mathrm{g})$ & $2827 \pm 195^{*}$ & $2019 \pm 56^{*}$ & & $2171 \pm 161$ & $1631 \pm 107^{*}$ \\
FSH $(15 \mu \mathrm{g})+$ & & & & \\
Tamoxifen $(10 \mu \mathrm{g})$ & $2058 \pm 122^{*}$ & $1638 \pm 189^{*}$ & & $2003 \pm 145 \dagger$ & $1576 \pm 94^{*}$ \\
\hline
\end{tabular}

Significantly different (Student's $t$ test) from controls: ${ }^{*} P<0.01 ; \dagger P<0.05$.

These results confirm the observation of Moon, Dorrington \& Armstrong (1975) that FSH has a stimulatory action on the aromatizing enzymes involved in the synthesis of oestradiol by the rat ovary and further demonstrate that Tamoxifen inhibits this stimulatory action.

It was previously suggested (Watson et al., 1975) that the oestradiol peak late on Day 3 of pregnancy in the rat was induced by a release of FSH which could act synergistically with $\mathrm{LH}$ and/or prolactin. The present data support this hypothesis and further imply that the mechanism of action of Tamoxifen at the ovarian level is to prevent the oestrogen surge by blocking the action of FSH. This could be the prime action of Tamoxifen but it is more likely to be additional to the known antioestrogenic effects at the uterine level (Skidmore, Walpole \& Woodburn, 1972). The fact that Tamoxifen also inhibits the synthesis of oestradiol and interferes with the FSH stimulus in the nonpregnant rat suggests that this could be an important mechanism whereby the compound inhibits ovulation in cyclic rats (Labhsetwar, 1970).

A considerable number of other non-steroidal antioestrogens, such as clomiphene, MER 25, $\mathrm{U} 11,100 \mathrm{~A}$ and $\mathrm{U} 11,555 \mathrm{~A}$, are known to act at the receptor (uterine) level to inhibit implantation. Studies with these compounds are at present being conducted to determine whether these have an action similar to that of Tamoxifen at the ovarian level, or if this property is unique to Tamoxifen.

\section{References}

LABHSETWAR, A.P. (1970) The role of estrogens in ovulation. A study using the estrogen antagonist ICI 46,474. Endocrinology 87, 542551.

Moon, Y.H., Dorrington, J.H. \& Armstrong, D.T. (1975) Stimulatory action of follicle-stimulating hormone on estradiol-17 $\beta$ secretion by hypophysectomised rat ovaries in organ culture. Endocrinology 97, 244-247.

Seaton, B. (1974) Data processing by computer: online or off-line? Computers and Biomedical Res. 7, 142-156.
Skidmore, J., Walpole, A.L. \& WoOdbuRN, J. (1972) Effect of some triphenylethylenes on oestradiol binding in vitro to macromolecules from uterus and anterior pituitary. J. Endocr. 52, 289-298.

WATSON, J. \& ALAM, M. (1976) Oestrogen synthesis during delayed implantation in the rat. Contraception 13, 101-107.

Watson, J., ANderson, F.B., Alam, M., O'Grady, J.E. \& HEALD, P.J. (1975) Plasma hormones and pituitary luteinizing hormone in the rat during the early stages of pregnancy and after post-coital treatment with Tamoxifen (ICI 46,474). J. Endocr. 75, 7-17.

Received 15 September 1976 